\title{
REAL ESTATE MARKET RISK IN BANK STOCK RETURNS: EVIDENCE FOR 15 EUROPEAN COUNTRIES
}

\author{
António Miguel MARTINS ${ }^{\text {a,*, Ana Paula SERRA }}{ }^{\text {b }}$, Francisco Vitorino MARTINS ${ }^{\text {b }}$ \\ a Universidade da Madeira, Caminho da Penteada, 9020-105 Funchal, Portugal \\ ${ }^{b}$ Universidade do Porto, Rua Dr. Roberto Frias s/n, 4200-464 Porto, Portugal
}

Received 9 October 2014; accepted 6 May 2015

\begin{abstract}
In countries with highly-developed financial systems bank portfolios have high exposure, directly or indirectly, to the real estate sector. Changes in the value of real estate can have a potentially significant impact on the default risk of banks and on their profitability as a result of high exposure to the real estate sector. This is especially critical during real estate crises, when bank losses tend to increase dramatically, placing the entire financial system at risk of collapse, as it was the case of the recent international subprime crisis. This article studies the sensitivity of bank stock returns to real estate returns in 15 European countries. The results indicate that bank stocks are sensitive to real estate market conditions. There is a positive relation between bank stock returns and real estate returns after controlling for general market conditions and interest rates changes.
\end{abstract}

KEYWORDS: Real estate; Mortgage lending; Banks; Asset pricing; Property prices

\section{INTRODUCTION}

In countries with highly-developed financial systems bank portfolios have high exposure, directly or indirectly, to the real estate sector. He et al. (1996), Lausberg (2004) and $\mathrm{Lu}$ and So (2005), indicate the existence of a high concentration of activity and assets in the real estate sector by banks in the USA, Germany, and in some Asian countries.

This way, in spite of all bank loans being vulnerable to general market conditions, the default risk on loans is influenced by a specific additional factor: bank real estate loans are affected by movements in the real estate market which are only indirectly related to the general economic conditions. Taking into account that the market value of banks is systematically influenced by the real estate market, the valuation models of bank stocks should include factors which reflect the conditions in the real estate market. Given that the financing of the real estate industry constitutes a significant part of the banks' loan portfolios, it is likely that real estate market conditions affect their stock prices.

* Corresponding author. E-mail: antonio.martins@staff.uma.pt
The inclusion of real estate market conditions as a risk factor has not been thoroughly considered in the literature. Studies looking the behavior of bank share prices focus on market and interest rate risks (see for example, Viale et al. 2009). The Asian financial crisis and, more recently, the subprime crisis highlighted the importance of the real estate risk. Herring and Wachter (1999) and $\mathrm{Lu}$ and So (2005) state that, prior to these crises, there was a tendency for over-investment in the real estate sector due to the high returns associated with this type of investment, potentially driving the occurrence of speculative bubbles in real estate prices in the vast majority of these markets. Furthermore, the increase in real estate prices tends also to bring about an increase in the value of collaterals, resulting in a perceived lower risk by the lender. For these reasons, the increase in real estate prices tends to produce increasing bank credit granting, which in turn, leads to new further rises in real estate prices. The existence of moral hazard, caused by high competition and the emphasis on size growth that followed the liberalization of the banking sector, and the loss of institutional memory regarding the possibility of 
property prices reversals, leads to banks taking excessive risks whereas the charged risk premium is insufficient to cover the potential losses (Herring, Wachter 1999). Jimenez et al. (2006) state that during booms, riskier borrowers obtain credit more easily and collateral requirements decreases. Dell'Ariccia et al. (2012) also found evidence of a decrease in lending standards associated with substantial increases in the number of loan applications. The authors show that lending standards declined to a greater extent in areas that experienced faster credit growth. They also note that the entry of new lenders contributed to the decline in lending standards. With specific reference to the subprime experience in the US, Demyanyk and van Hemert (2011) report that loan quality consistently declined for the six years prior to the crisis in 2007. They argue that the high level of house price appreciation observed in the US during this period contributed to the decline in loan quality.

A drop in real estate prices brings about a reduction in bank equity, as a consequence of the reduction in the value of the real estate asset and loan portfolios held by banks, and by the corresponding reduction of collaterals. Also, the drop in real estate prices tends to result in greater awareness by banks of the perceived risks of real estate loans. For these reasons, it is very likely that a significant decrease in bank credit granting will occur. Added to this, supervisors and regulators react to the scenario of reduced bank equity with additional requirements of solvability and more stringent rules for the risk evaluation and provisioning for bad loans of real estate assets. These measures result in a further reduction in the bank credit magnifying the downfall movement in real estate prices. This seems to be the mechanism of transmission between real estate market conditions and bank stock risk and returns.

In this article, we study the sensitivity of bank returns with regards to real estate returns in 15 European countries (EU-15). In particular, we look at the relationship between the banking industry stock market returns and the returns of real estate companies, for each of the EU-15 countries in our sample, in order to assess the reasonableness of the hypothesis of a priced risk factor in real estate returns of European banks. In our analysis we use a three-factor risk model and an extended FamaFrench model (1992 and 1993).

Given that there are significant differences between the EU-15 countries and the US banking industry and among the 15 countries in respect to the characteristics of their mortgage markets (Acharya et al. 2011) and other real estate market institutional features, and in the dynamics of real estate prices (Miles, Pillonca 2008), we explore whether bank stocks react differently to real estate market conditions in each of those countries.

The results of our research indicate that the stocks of the EU-15 banks are sensitive to the changes in real estate conditions. We find a positive significant relation between bank stock returns and real estate returns, even after controlling for general market conditions and interest rates changes.

The remainder of the article is organized as follows. In section 2 we present a review of the previous related literature and main empirical findings. The methodology and sample are discussed in section 3. The empirical results are presented and discussed in section 4 . The conclusions appear in section 5 .

\section{LITERATURE REVIEW}

Studies looking at the importance of real estate market conditions on bank stock returns are fairly recent and almost exclusively look at the US market. The vast majority of studies that examine common risk factors in bank stock returns uses a two-factor risk model, which implies that bank stock returns are influenced by general market conditions and by movements in interest rates. For example, Flannery and James (1984) and Viale et al. (2009) find a significant negative relation between the change in interest rates and bank stock returns, conditional on the balance-sheet exposure to interest rate risk.

Allen et al. (1995) argue that the equity value of banks reacts significantly to real estate market conditions particularly when banks have a significant exposure to the real estate sector and the exposure is significantly influenced by changes in the conditions of the real estate sector.

\subsection{Real estate market conditions and bank stock returns}

Although mortgage loans are exposed to interest rate risk, they are also exposed to default risk. As previously stated, the default risk is at least in part a function of changes in the value of real estate. When there is a decrease in the value of loan collaterals, there is an increased probability 
of default due to the decreased value of loans with collateral. Thus, given that the value of collateral has an impact on the value of loans and mortgages, the potential loss to a bank as a result of default risk is inversely related to the value of the collateral.

While the real estate market and overall stock market indices are positively correlated ${ }^{1}$, the two markets do not always behave identically. Quan and Titman (1999) study the relation between stock returns and changes in property values and rents for a data of 17 different countries over 14 years. They find, with the exception of Japan, the contemporaneous relation between annual real estate price changes and stock returns is not statistically significant. Yet, over longer measurement intervals, they find a significant relation between stock returns and both rents and property value changes. Thus the impact of changes in real estate market conditions, measured by the banks' exposure to this factor, is thus not completely captured by the exposure of bank stocks to the stock market. While a positive correlation between real estate and stock market prices expected, given that both markets are affected by the level of economic activity, several factors can reduce the correlation between the two time series. For example, stock prices may increase because of increased investment opportunities in an economy's corporate sector. This increase in investment opportunities could in turn lead to increases in real interest rates, which could reduce the value of property.

Based on the arguments above, bank stock returns are related to changes in real estate market conditions, conditional on the bank's asset and loan exposure to the real estate market.

\subsection{Previous empirical findings}

Table 1 shows a summary of the main studies looking at the relationship between market capitalization of banks and the real estate market. The majority of these studies were done for the US market and all of them use multi-factor models. The variables used and the time periods considered vary substantially. This gives greater robustness to the evidence found of a real estate risk factor in bank stock returns.

\footnotetext{
${ }^{1}$ Mei and Lee (1994) and Mei and Saunders (1995) find a correlation coefficient between real estate returns and general stock market returns of respectively, 0.723 and 0.639 in the US. Lu and So (2005) report correlation coefficients between 0.502 and 0.822 for seven Asian countries.
}

The studies included in Table 1 are for the US market and the Asian markets during periods of real estate market crises, and where these had a significant effect on the profitability of the banking industry and consequently on the assessment of the value of banks by investors.

In addition, Lu and So (2005) present a set of additional studies which show the existence of a significant relationship between the real estate market and the market capitalization of banks. Peek and Rosengren (1994) state that large bank equity losses are the result of exposure to high-risk mortgage loans. Peek and Rosengren (1996) further show that banks with low capital ratios tend to reduce real estate credit grants in a substantial manner after regulatory measures are introduced. Ghosh et al. (1997) show also that the prices of financial institutions react negatively to announcement of adverse news concerning the real estate industry.

Hancock and Wilcox (1993, 1994 and 1997) carried out a set of studies on the interaction between loan grants and real estate market activity. They show that the flow of bank loans in the US in 1990 declined primarily due to problems related to the real estate industry, and suggest that the reduction of bank equity had a significant negative effect on the residential and commercial real estate market.

\subsection{The European market}

Tsatsaronis and Zhu (2004), Acharya et al. (2011) ${ }^{2}$ and Martins et al. $(2012)^{3}$, argue that there are significant differences among the EU countries, and between the EU and the US in the case of Acharya et al. (2011), with regard to the charac-

\footnotetext{
${ }^{2}$ Acharya et al. (2011) identify the existence of three major funding models for mortgage credit in developed economies: the classic deposit-based system; the Market-Backed Security (MBS) based system (used extensively in the US); and the mortgage or covered bond system (popular in continental Europe). Covered bonds are issued by banks and share many features with MBS, but they also differ in important ways. Most importantly, investors in covered bonds have not only a general claim on the issuing bank but also on the underlying mortgage collateral in the event that banks default. In Germany "Hypotheken Pfandbriefe" represented $44 \%$ of all the mortgage bonds issued in the EU, followed by Denmark (29\%) and Sweden (15\%).

${ }^{3}$ Martins et al. (2012) develop a cluster analysis that reveals significant differences in terms of Real Estate institutional characteristics across the EU-15 countries. Among the five clusters found, the two extremes were the cluster formed by Spain, Ireland and the United Kingdom, with a less conservative mortgage credit system, a sparse rental market and a generous fiscal system; and the one formed by Germany and Austria, with a conservative mortgage credit system, a large rental market and a less generous fiscal system.
} 
Table 1. Empirical studies on the relationship between market capitalization of banks and the real estate market

\begin{tabular}{|c|c|c|}
\hline & Sample and variables & Results \\
\hline \multicolumn{3}{|l|}{ I. US market } \\
\hline Mei and Lee (1994) & $\begin{array}{l}\text { i. Indices: Banking Industry Stock Returns; Dividend Yield; } \\
\text { T-bill rates; Income Yield on the Wilshire Real Estate In- } \\
\text { dex; Spread between AAA Bonds and T-bills (default risk } \\
\text { factor). } \\
\text { ii. Others: Stock Market Returns: Government Bonds Yield }\end{array}$ & $\begin{array}{l}\text { There is a real estate risk premi- } \\
\text { um for all stocks in addition to the } \\
\text { stock market and the interest rate } \\
\text { risk premiums. }\end{array}$ \\
\hline
\end{tabular}

ii. Others: Stock Market Returns; Government Bonds Yield Changes; REITs; Small Caps Returns; Russell-NCREIF Returns.

iii. Period: 1978-1989.

iv. Quarterly Returns.

$\begin{array}{ll}\begin{array}{l}\text { Mei and Saunders } \\ \text { (1995) }\end{array} & \text { i. Indices: Returns of different portfolios of } 180 \text { US-banks; } \\ & \text { Dividend Yield; T-bill rates; Cap Rate constructed as a }\end{array}$ (1995)

Allen et al. (1995)

He et al. (1996) ratio of net stabilized earnings to the market-value (market price) of a well diversified property portfolio (ACLI cap-rate); Spread between AAA Bonds and T-bills (default risk factor); January dummy.

ii. Others: Stock Market Returns; Government Bonds Yields; REITs.

iii. Period: 1971-1989.

iv. Monthly Returns.

i. Indices: Stock Returns of various portfolios of 125 USbanks; S\&P 500 Returns; T-Bond rates and Unexpected TBond Yield Changes, NAREIT Equity REIT index returns.

ii. Others: Balance sheet data.

iii. Period: 1979-1992.

iv. Monthly Returns.

i. Indices: Stock Returns of various portfolios of 166 USbank holding companies; four different stock market proxies; three proxies of Interest Rates; six Real Estate returns proxies.

ii. Others: Balance sheet data.

iii. Period: 1986-1991.

iv. Weekly and Monthly Returns.
A premium for real estate risk is increasingly apparent in bank stocks, presumably reflecting these banks' growing exposures in this area; it could be as high as the premium for interest rate risk.
There is a positive relationship between monthly bank returns and the real estate index returns; the sensitivity of bank values to the real estate market has increased over time; the bank-specific sensitivity is positively related to the bank's balance sheet exposure to real estate returns.

Bank stocks are very sensitive to changes in real estate returns; banks with a larger portion of their total loans invested in real estate are more sensitive to real estate returns.

II. Asian markets

Lu and So (2005)

i. Indices: Stock Returns of various portfolios of US banks; Stock Market returns; Expected and Unexpected threemonth Inter-bank Interest Rates; Stock Returns of portfolio of Real Estate companies.

ii. Others: Interest Rate Spread, defined as the difference between the three-month Inter-Bank Rates and the Deposit Rates.

iii. Period: 1995-1999.

iv. Daily Returns.
Listed banks are exposed to real estate risk both before and after the crisis but the exposure increased in the post-crisis period. The large effect on the real estate sector on bank stock returns implies that, after the crisis, the hidden risk of real estate collateral on the bank lending process was unveiled. teristics of their mortgage markets ${ }^{4}$. For example, while residential mortgage loans in terms of GDP declined in Germany from 55.6\% in 1999 to $43.2 \%$ in 2008 , there was a substantial increase of this asset class in other countries. Specifically, Spain and Ireland almost tripled the value of residential loans during this period. Further, there are

\footnotetext{
4 These differences relate to a variety of aspects including: the prevailing interest rates; the possibility of equity withdrawal; the level of LTV (Loan-to-Value) ratios; the indorsed property valuation methods; and the availability of asset securitization.
}

huge differences in the real estate price dynamics across Europe: Miles and Pillonca (2008) refer the presence of house price bubbles in countries like Spain, Sweden, Belgium and UK, related with different types of mortgage arrangements, while in most of the other European countries the house prices seem to be driven by fundamentals. These and other institutional differences in real estate markets may lead to a different relationship between bank returns and real estate returns across European countries. 


\section{METHODOLOGY AND SAMPLE}

\subsection{Methodology}

The literature reviewed above shows the existence of a close relationship between the valuation of banks and banking activity, and the real estate industry, in the U.S. and in Asia. Yet the issue was not analyzed for the EU banking industry.

To carry out the analysis of the relationship between bank stock returns and real estate market conditions we use two models: a three-factor risk model (market risk, interest rate risk and real estate market risk), and an extended Fama-French model with a real estate market risk factor.

The three-factor model has the following specification:

$$
R_{j t}=\beta_{0 j}+\beta_{m j} R_{m j t}+\beta_{I j} I_{j t}+\beta_{R j} R_{R j t}+e_{j t},
$$

where: $R_{j t}$, is the banking industry stock market return in country $j$ in period $t ; R_{m j t}$ is the general stock market return in country $j$ in period $t ; I_{j t}$ is the interest rate factor in country $j$ in period $t$ and $R_{R j t}$ is the real estate industry stock market return in country $j$ in period $t . \beta_{m j}$, $\beta_{I j}$ and $\beta_{R j}$ measure bank stock returns sensitivities relative to the general stock market, interest rate movements and the real estate market. $\beta_{0 j}$ is the independent term and $e_{j t}$ is the error term. This three-factor model is the natural extension of the two-factor asset pricing model used in earlier studies (for example, Flannery and James (1984) and Viale et al. 2009) to analyze the effects of interest rate changes and market returns on bank stock returns.

To test the hypothesis of the importance of real estate market factor on bank stock returns, we also use an extended Fama and French return generating model:

$$
\begin{aligned}
& R_{j t}=\beta_{0 j}+\beta_{m j} R_{m j t}+\beta_{I j} I_{j t}+\beta_{R j} R_{R j t}+ \\
& \beta_{v j} H M L_{j t}+\beta_{s j} S M B_{j t}+e_{j t},
\end{aligned}
$$

where: $H M L^{5}{ }_{j t}$ and $S M B^{6}{ }_{j t}$ are added to equation (1) and measure, respectively, the excess historical returns of value stocks vis a vis growth stocks, and the excess returns of small stocks vis a vis large

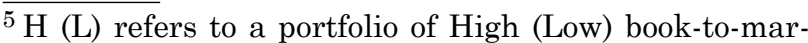
ket (BTM) stocks. HML means "High minus Low" and measures the spread in returns between the two portfolios. Book-to-Market compares the book value of equity with equity market capitalization (number of stocks multiplied by the stock price. High (Low) BTM stocks are also labelled as value (growth) stocks.

${ }^{6} \mathrm{~S}$ (B) refers to a portfolio of Small (Big) size stocks. SMB means "Small minus Big" and measures the spread in returns between the two portfolios. Size is given equity market capitalization (number of stocks multiplied by the stock price.
}

capitalization stocks. The $H M L$ and $S M B$ return factors were constructed using $\mathrm{MSCI}^{7}$ indices, in the following manner:

$$
\begin{aligned}
& \text { SMB = ("Small Cap Value" + "Small Cap } \\
& \text { Growth")/2 - ("Large Cap Value" + "Large } \\
& \text { Cap Growth")/2; }
\end{aligned}
$$

$H M L=(" L a r g e$ Cap Value" + "Small Cap Value")/2 - ("Large Cap Growth" + "Small Cap Growth")/2.

The estimation procedure is the Generalized Method of Moments (GMM) ${ }^{8}$, so that the $t$ statistics for the estimated coefficients are corrected for heterokedasticity and autocorrelation.

Given the internationalization of business activities and the integration of the banking industry at a regional and international level, we also compute sensitivities of bank returns using regional real estate industry stock market indices ${ }^{9}$.

Finally, in order to test a change in the sensitivities of bank stock returns to general stock market returns, interest rate changes and the real estate market conditions, due to the emergence of the subprime crisis, a variable dummy $D_{t}$ is incorporated into Equation (1), with a value of 1, for the period from 18 June 2007 (daily data) or June 2007 (monthly data) to the end of $2008^{10}$, as follows:

$$
\begin{aligned}
& R_{j t}=\beta_{0 j}+\beta_{m j} R_{m j t}+\beta_{I j} I_{j t}+\beta_{R j} R_{R j t}+\beta_{1 j} D_{t}+\beta_{2 j} \\
& D_{t}^{*} R m_{j t}+\beta_{3 j} D_{t}^{*} I_{j t}+\beta_{4 j} D_{t}^{*} R_{R j t}+e_{j t .}
\end{aligned}
$$

The sensitivities of bank returns to economic factors depend on specific characteristics of banks ${ }^{11}$. In this paper we estimate the exposures of the banking industry index of each of the $15 \mathrm{EU}$ countries, instead of individual banks. Therefore we do not look into the factors driving the cross sectional variation observed in individual bank sensitivities.

${ }^{7}$ Morgan Stanley Capital International. Source: The Thomson Reuters DATASTREAM. All indices are weighted by market capitalization.

${ }^{8}$ Mei and Lee (1994) and Mei and Saunders (1995) also use GMM to estimate the sensitivities of U.S. bank stocks to real estate returns.

9 The regional real estate indices are computed based upon the stock returns of the real estate companies in certain groups of countries within the EU.

${ }^{10}$ June, 182007 corresponds to the bankruptcy announcement of Bear Stearns. This date is widely accepted as the "official" start of the subprime crisis. See, for example, Crouhy et al. (2008).

${ }^{11}$ For example, Jahankhani and Lynge (1980) find that bank sensitivities are related to dividend payout ratios, variability of deposits and to the ratio between loans and deposits. Flannery and James (1984) show that the sensitivity to interest rates appears to be related to the mismatch of asset durations against liabilities. 


\subsection{Sample}

\subsubsection{Three-Factor model and the Fama-French extended model}

We use daily and monthly returns. Three time frames are used in the estimates of the two models:

(1) Total Period - this time frame differs from country to country, by virtue of the depth of the series used in the model estimates. This period goes from the start date of the index for each of the EU-15 countries to 2008:12.

(2) for a sub-period between 2002 and 2006 (five-year time frame); and

(3) for a sub-period between 1997 and 2006 (ten-year time frame).

While we could argue that the crisis was not over by the end of 2008, and there were indeed more bad news for the banks in the following years, the largest part of the banking write-downs and losses associated with the real estate market crisis had been publicly disclosed. The turbulence in the following years did not have to do only with the real estate market. Following the Lehmann Bros bankruptcy, there was first a severe bank liquidity crisis with spillovers into the bond and stock markets that drove the behavior of bank stock returns in 2009, and in 2010 and 2011 many banks were strongly hit again by the sovereign debt crisis, impacting their stock price behavior ${ }^{12}$.

To define the factors of the three-factor model and of the Fama-French extended model, we use the variables proposed in prior studies (mentioned in Table 1) depending on its availability for the European markets.

With respect to the dependent variable, banking industry stock return indices are used for each country $^{13}$. We are not aware of a survivorship bias in DATASTREAM indices.

With respect to the real estate market risk proxy, we use real estate companies' stock market indices ${ }^{14}$. This option follows $\mathrm{Lu}$ and So (2005). The absence of REITs indices for the majority of European countries contributed much to our choice of proxy. Only Germany, Belgium, France, Holland

\footnotetext{
$\overline{12}$ We thank to an anonymous referee for this comment.

${ }^{13}$ Source: Thomson Reuters DATASTREAM - "Total Return Index - Banks." The index reflects the price and dividend performance of listed banks' stocks. These are DATASTREAM proprietary indices.

${ }^{14}$ Source: Thomson Reuters DATASTREAM - "Total Return Index - Real Estate." For Ireland and Luxembourg the real estate market proxy refers to the UK and BENELUX. The index reflects the price and dividend performance of listed real estate companies' stocks. These are DATASTREAM proprietary indices.
}

and the United Kingdom have available long series of REITs returns. Notwithstanding the lack of consensus that REITs returns constitute the perfect measure of real estate market fundamentals ${ }^{15}$, these indices have been used in the studies carried out for the US market (see Table 1). In this regard, Allen et al. (1995) mention that the use of REITs indices is justified because they are based on market transactions in opposition to real estate market return measures based on valuations made by surveyors. According to the authors, the latter do not constitute a perfect measure of real estate market activity due to the price smoothing problems (see also in this respect, Geltner, 1991 and Geltner, Ling 2006). Given that the industry stock market index for real estate companies, like the REITs indices, is based on market transactions, it is expected to constitute an unbiased measure of real estate market fundamentals.

As stated in Lu and So (2005), the real estate stock returns are not exempt from potential problems. The two potential problems of using real estate companies market returns as a proxy for real estate market conditions are: 1) there is little consensus across countries regarding the definition of a Real Estate company and 2) listed companies may not be representative of the underlying real estate market.

The real estate industry stock market indices include construction work, real estate investment and development companies. For the majority of the companies, operations refer to retail, offices and residential properties. While our results could be different if we used two types of real estate indices (commercial and consumer), DATASTREAM indices do not distinguish between commercial and consumer real estate companies ${ }^{16}$.

Kan et al. (2004) report that, for the US market, the volatility of commercial property prices is higher than that of residential property prices. Yet lagged, contemporaneous, and forward commercial property prices are positively correlated with residential property prices.

Following He et al. (1996), we use unexpected yield changes on 10-year government bonds as

\footnotetext{
15 For a throughout discussion, see Allen et al. (1995).

${ }^{16}$ We thank an anonymous referee for this comment. To investigate this issue in further detail we would have to go through the individual reports of each of the real estate companies that are included in the indices, to find out whether they operate mostly in commercial or in housing markets.
} 
the proxy for the interest rate risk factor ${ }^{17}$. To compute unexpected changes in government bond yields we use the procedure proposed by Flannery and James (1984). The changes in yields are calculated as follows:

$$
\Delta \% \text { yield }_{t}=\left(\text { yield }_{t}-\text { yield }_{t-1}\right) / \text { yield }_{t-1} .
$$

To estimate the unexpected government bond interest rates, the following $A R(p)$ model is used 18 .

$$
\Delta \% \text { yield }_{t}=\varphi_{0}+\sum_{k=1, . ., p} \varphi_{k} \Delta \% \text { yield }_{t-k}+w_{t} .
$$

The error term of equation (7), $w_{t}$, represents the unexpected change of bond interest rate yields.

The stock market indices for each EU-15 country are used as the benchmark for general stock market returns ${ }^{19}$.

\section{RESULTS}

\subsection{Descriptive statistics}

Table 2 presents the summary of the descriptive statistics for the index returns of banks and real estate companies for each the 15 European countries analyzed.

Panel A of Table 2 presents the average, the median and the variance of industry index stock returns for banks and real estate companies. Sweden, the United Kingdom, Greece, Ireland, Spain, Finland and Denmark are the countries with higher average returns for the banking industry.

Panel B of Table 2 shows that the banking industry index is positively and significantly correlated to the real estate companies' stock market industry index. This is consistent with the argument that banks are exposed to real estate market risk. There is also a significant correlation between market returns and either banking or real estate industry returns but banks show higher correlation with the general stock market index. Panel C of Table 2 presents the values of market capitalization and the number of constituent stocks that integrate DATASTREAM banking industry and real estate indices. The United Kingdom, Belgium and Spain show a higher average market capitalization, which is not surprising when you consider that some of the main European banks are included in these indices.

\footnotetext{
${ }^{17}$ Source: Thomson Reuters DATASTREAM - "Bond Yield Government 10 Years."

${ }^{18}$ The number of lags is given by a likelihood ratio test.

${ }^{19}$ Source: Thomson Reuters DATASTREAM - "Total Return Index - Market". The index reflects the price and dividend performance of the stock market and includes all listed stocks.
}

\subsection{Sensitivities of bank returns to real estate}

Table 3 shows the estimates of the three-factor model as defined by equation $(1)^{20}$. The estimated regressions for the different time periods aim to test the robustness of the results over different periods of time. We exclude 2007 and 2008. These are the years of the outbreak and the large impact of the subprime crisis.

In these regressions, the dependent variable is the banking industry stock market returns. Table 3 shows that: 1) bank returns are positively and significantly related to the returns of real estate companies in most EU-15 countries; 2) the threefactor model seems to capture in a reasonable manner the relationship between bank returns and the risk factors considered, and the average contribution of omitted variables seems to be small and economically insignificant; 3) the more significant effects come from the market itself, as indicated by the highly significantly coefficients associated to this factor; 4) interest rates unexpected changes are not statistically significant in determining bank stock returns for the majority of EU-15 countries ${ }^{21}$. Lu and So (2005) find similar results in their study of the Asian market. According to them, equation (1) may suffer from multicolinearity problems. As such the effects of interest rates may be subsumed by the returns of real estate companies ${ }^{22,} 23$.

Table 4 shows the influence of the subprime crisis on possible changes in the sensitivities of bank stock returns to overall market risk, market interest rates and the movements in the real estate market. The results show an greater influence of the real estate market movements on the returns of Irish, Spanish and British banks after the

${ }^{20}$ We also run regressions using daily returns. Results are similar and are available upon request.

${ }^{21}$ To test the robustness of the results above, we run the regressions using the REITs returns as proxy for the real estate market returns for the subset of markets with REITs indices. The results, not disclosed here, confirm that bank stock returns are significantly influenced by the real estate market. Results are available upon request.

${ }^{22}$ Given that interest rate changes and real estate assets are positively highly correlated, we run the regression including either interest rate changes or real estate companies' returns. The two variables are significant and estimates are similar. To overcome multicolinearity we also run regressions using orthogonalized real estate returns. Results are similar and are available upon request.

${ }^{23}$ Overall, these conclusions are supported by the extended Fama-French model results and are available upon request. 
Table 2. Descriptive statistics - banking and real estate stock market industry indices

Panel A. averages, medians and variances of index returns

\begin{tabular}{llllllll}
\hline Country & Start & Banking & & & Real estate & \\
\cline { 3 - 5 } \cline { 5 - 6 } & & $\begin{array}{l}\text { Average } \\
\left(10^{-3}\right)\end{array}$ & $\begin{array}{l}\text { Median } \\
\left(10^{-3}\right)\end{array}$ & $\begin{array}{l}\text { Variance } \\
\left(10^{-3}\right)\end{array}$ & $\begin{array}{l}\text { Average } \\
\left(10^{-3}\right)\end{array}$ & $\begin{array}{l}\text { Median } \\
\left(10^{-3}\right)\end{array}$ & $\begin{array}{l}\text { Variance } \\
\left(10^{-3}\right)\end{array}$ \\
\hline Germany & $1993 / 10 / 01$ & 0.008 & 0.110 & 0.276 & 0.494 & 0.015 & 0.306 \\
Austria & $1991 / 10 / 11$ & 0.252 & 0.023 & 0.227 & -0.012 & -0.004 & 0.115 \\
Belgium & $1989 / 06 / 06$ & 0.078 & 0.149 & 0.268 & 0.215 & 0.122 & 0.085 \\
Denmark & $1991 / 10 / 08$ & 0.405 & 0.342 & 0.199 & 0.247 & 0.000 & 0.125 \\
Spain & $1991 / 04 / 05$ & 0.430 & 0.304 & 0.231 & 0.277 & 0.118 & 0.163 \\
Finland & $1998 / 06 / 02$ & 0.425 & 0.035 & 0.363 & 0.222 & 0.186 & 0.354 \\
France & $1987 / 07 / 09$ & 0.333 & 0.073 & 0.317 & 0.323 & 0.256 & 0.071 \\
Greece & $1990 / 01 / 02$ & 0.469 & 0.042 & 0.398 & 0.823 & 0.063 & 0.714 \\
Holland & $1986 / 05 / 16$ & 0.344 & 0.374 & 0.438 & 0.198 & 0.321 & 0.073 \\
Ireland & $1986 / 05 / 28$ & 0.457 & 0.142 & 0.390 & 0.319 & 0.242 & 0.122 \\
Italy & $1987 / 04 / 01$ & 0.285 & 0.264 & 0.198 & 0.264 & 0.093 & 0.212 \\
Luxembourg & $1998 / 12 / 31$ & 0.079 & 0.050 & 0.130 & 0.263 & 0.495 & 0.075 \\
Portugal & $1993 / 07 / 19$ & 0.213 & 0.148 & 0.125 & 0.913 & 0.086 & 1.101 \\
United Kingdom & $1986 / 05 / 16$ & 0.528 & 0.234 & 0.277 & 0.319 & 0.242 & 0.122 \\
Sweden & $1988 / 11 / 29$ & 0.540 & 0.078 & 0.474 & 0.447 & 0.127 & 0.243 \\
\hline Panel B. Corr
\end{tabular}

Panel B. Correlation of index returns

\begin{tabular}{|c|c|c|c|c|c|c|}
\hline \multirow[t]{2}{*}{ Country } & \multicolumn{2}{|c|}{ Banking vs. real estate } & \multicolumn{2}{|c|}{ Banking vs. market } & \multicolumn{2}{|c|}{ Real estate vs. market } \\
\hline & Daily & Monthly & Daily & Monthly & Daily & Monthly \\
\hline Germany & $0.319^{* * *}$ & $0.445^{* * *}$ & $0.679^{* * * *}$ & $0.787^{* * *}$ & $0.282^{* * *}$ & $0.376^{* * *}$ \\
\hline Austria & $0.265^{* * *}$ & $0.423^{* * *}$ & $0.765^{* * *}$ & $0.762^{* * *}$ & $0.397^{* * *}$ & $0.525^{* * *}$ \\
\hline Belgium & $0.197^{* * *}$ & $0.509^{* * *}$ & $0.831^{* * * *}$ & $0.887^{* * *}$ & $0.335^{* * *}$ & $0.641^{* * *}$ \\
\hline Denmark & $0.173^{* * *}$ & $0.299^{* * *}$ & $0.727^{* * *}$ & $0.669^{* * *}$ & $0.208^{* * *}$ & $0.312^{* * *}$ \\
\hline Spain & $0.430^{* * *}$ & $0.534^{* * *}$ & $0.924^{* * *}$ & $0.915^{* * *}$ & $0.535^{* * *}$ & $0.684^{* * *}$ \\
\hline Finland & $0.205^{* * *}$ & $0.317^{* * *}$ & $0.313^{* * *}$ & $0.350^{* * *}$ & $0.211^{* * *}$ & $0.148^{*}$ \\
\hline France & $0.365^{* * *}$ & $0.422^{* * *}$ & $0.746^{* * * *}$ & $0.760^{* * *}$ & $0.433^{* * *}$ & $0.471^{* * *}$ \\
\hline Greece & $0.234^{* * *}$ & $0.141^{* * *}$ & $0.925^{* * *}$ & $0.962^{* * *}$ & $0.287^{* * *}$ & $0.153^{* *}$ \\
\hline Holland & $0.232^{* * *}$ & $0.479^{* * *}$ & $0.669^{* * *}$ & $0.788^{* * *}$ & $0.417^{* * *}$ & $0.514^{* * *}$ \\
\hline Ireland & $0.280^{* * *}$ & $0.370^{* * *}$ & $0.727^{* * *}$ & $0.716^{* * *}$ & 0.017 & $0.344^{* * *}$ \\
\hline Italy & $0.389^{* * *}$ & $0.589^{* * *}$ & $0.849^{* * * *}$ & $0.869^{* * *}$ & $0.437^{* * *}$ & $0.578^{* * *}$ \\
\hline Luxembourg & $0.166^{* * *}$ & $0.368^{* * *}$ & $0.293^{* * *}$ & $0.409^{* * *}$ & $0.202^{* * *}$ & $0.323^{* * *}$ \\
\hline Portugal & $0.425^{* * *}$ & $0.557^{* * *}$ & $0.779^{* * *}$ & $0.827^{* * *}$ & $0.514^{* * *}$ & $0.595^{* * *}$ \\
\hline United Kingdom & $0.492^{* * *}$ & $0.572^{* * *}$ & $0.783^{* * *}$ & $0.777^{* * *}$ & $0.607^{* * *}$ & $0.625^{* * *}$ \\
\hline Sweden & $0.373^{* * *}$ & $0.509^{* * *}$ & $0.659^{* * *}$ & $0.658^{* * *}$ & $0.496^{* * *}$ & $0.627^{* * *}$ \\
\hline
\end{tabular}

Panel C. Number of constituents and market capitalization

\begin{tabular}{|c|c|c|c|c|}
\hline \multirow[t]{2}{*}{ Country } & \multicolumn{2}{|c|}{ Real estate industry index (DATASTREAM) } & \multicolumn{2}{|c|}{ Banking industry index (DATASTREAM) } \\
\hline & $\begin{array}{l}\text { Number } \\
\text { of constituents }{ }^{\mathrm{a}}\end{array}$ & $\begin{array}{l}\text { Average market } \\
\text { capitalization ( } € \text { Million) }\end{array}$ & $\begin{array}{l}\text { Number } \\
\text { of constituents }^{b}\end{array}$ & $\begin{array}{l}\text { Average market } \\
\text { capitalization (€ Million) }\end{array}$ \\
\hline Germany & 13 & 683 & 6 & 9,446 \\
\hline Austria & 7 & 1,243 & 6 & 3,095 \\
\hline Belgium & 19 & 182 & 4 & 12,812 \\
\hline Denmark & 1 & 432 & 8 & 1,930 \\
\hline Spain & 12 & 434 & 9 & 11,033 \\
\hline Finland & 2 & 927 & 1 & 1,677 \\
\hline France & 27 & 1,850 & 10 & 12,486 \\
\hline Greece & 2 & 569 & 10 & 2,152 \\
\hline Holland & 10 & 1,046 & 1 & 1,277 \\
\hline Ireland & 0 & & 2 & 7,548 \\
\hline Italy & 5 & 976 & 19 & 8,267 \\
\hline Luxembourg & 0 & & 2 & 1,084 \\
\hline Portugal & 1 & 53 & 4 & 2,805 \\
\hline United Kingdom & 29 & 1,022 & 5 & 36,976 \\
\hline Sweden & 7 & 927 & 5 & 7,112 \\
\hline
\end{tabular}

${ }^{a}$ and ${ }^{b}$ give the number of constituent stocks included in the real estate companies and banks included in the Real Estate Industry Indices and in the Banking Industry Indices, respectively.

$* * *,{ }^{* *}$ and ${ }^{*}$ denote statistical significance at $1 \%, 5 \%$ and $10 \%$ levels for bilateral tests.

This table shows the descriptive statistics of the banking industry index and real estate index returns, based on daily observations for each of the EU-15 countries. The analysis period starts in the period indicated in the table and ends in 2008:12 (or 2018/12/31). For Ireland and Luxembourg, real estate returns are proxied by the real estate returns index of the UK and of Benelux, respectively, due to the lack of data for real estate companies in the domestic market. Panel A shows average, median and average returns of the banking industry and real estate index returns. Panel B shows the correlations between the banking industry index (Banking) and real estate companies index (Real Estate) and the overall market stock return index (Market). Panel C reports the values of market capitalization $(€$ Million) and number of companies that comprise the banking industry return index and real estate companies return index of DATASTREAM. 


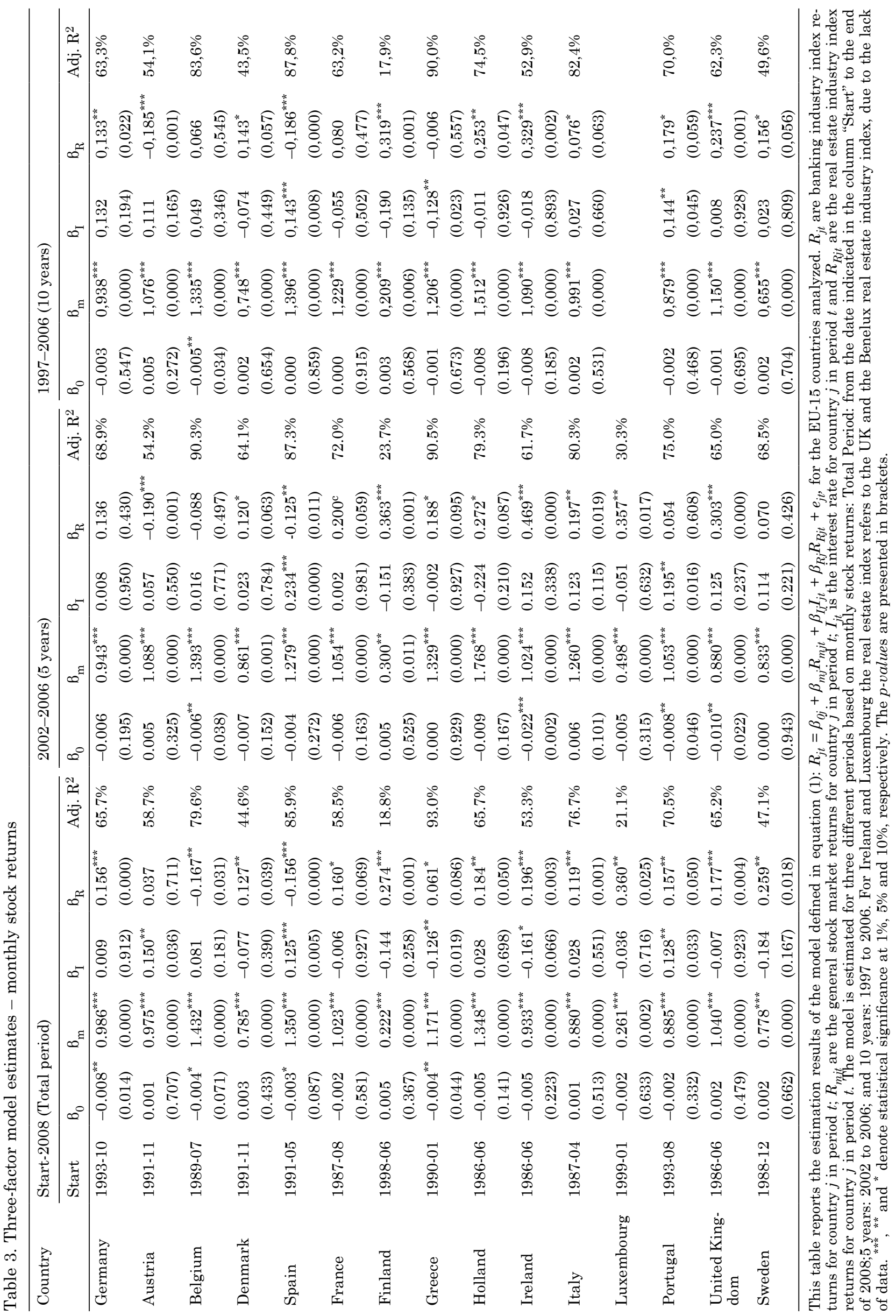




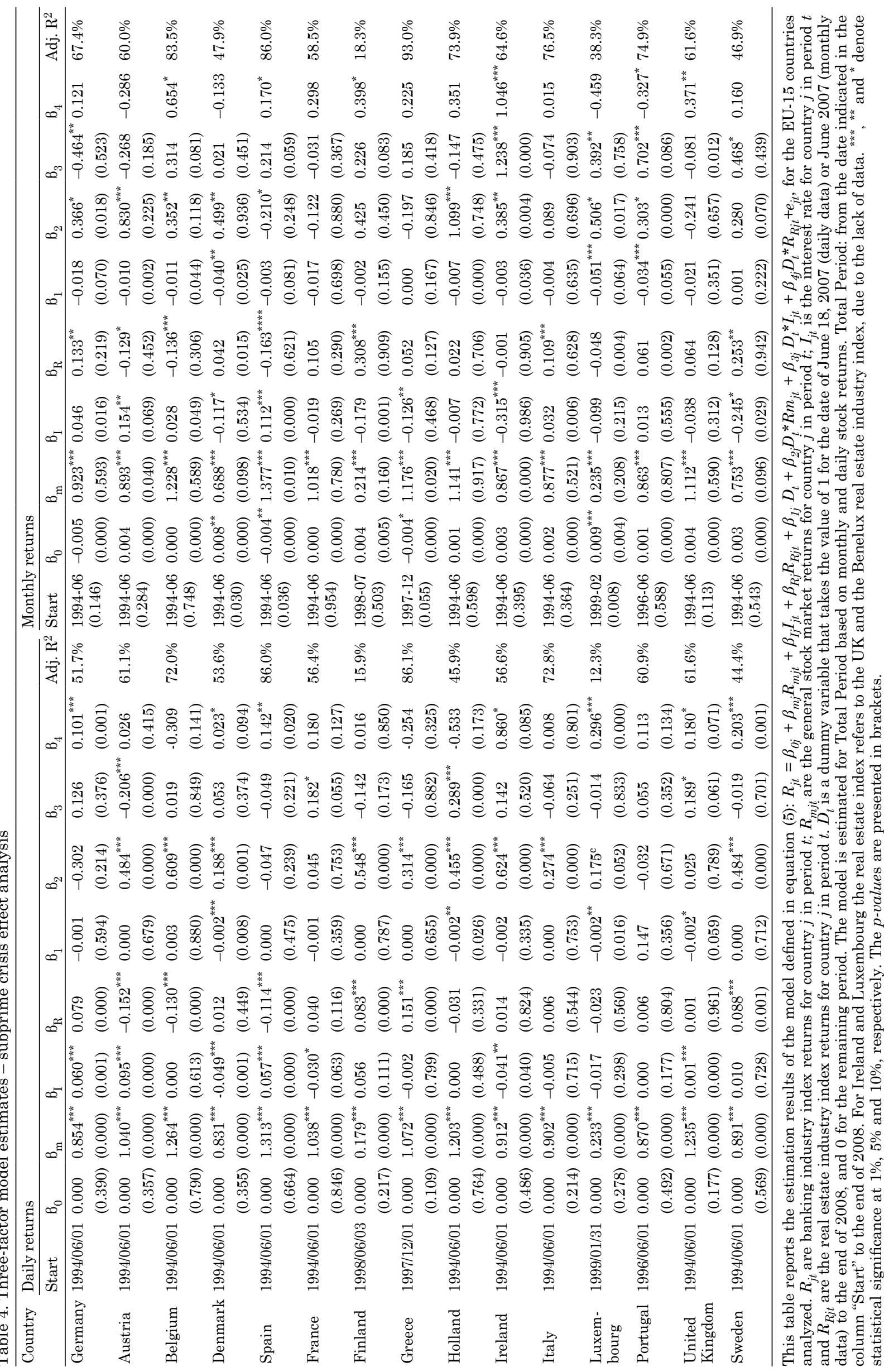


Table 5. EU-15 listed banks with real estate market exposure at a regional level

\begin{tabular}{|c|c|c|c|c|c|c|}
\hline \multirow[t]{2}{*}{ Country } & \multirow{2}{*}{$\begin{array}{l}\text { \# Listed } \\
\text { banks }\end{array}$} & \multicolumn{5}{|c|}{ 'Non domestic' banks } \\
\hline & & \# Banks & Name & $\begin{array}{l}\text { Main regional } \\
\text { market }\end{array}$ & $\begin{array}{l}\text { Non-domestic } \\
\text { asset weight } \\
(\%)\end{array}$ & Ranking $^{1}$ \\
\hline \multirow[t]{2}{*}{ Germany } & \multirow[t]{2}{*}{24} & \multirow[t]{2}{*}{3} & $\begin{array}{l}\text { Deutsche Bank } \\
\text { Commerzbank }\end{array}$ & $\begin{array}{l}\text { Europe } \\
\text { Europe }\end{array}$ & $\begin{array}{l}47.0 \\
40.0\end{array}$ & $\begin{array}{l}1 \\
2\end{array}$ \\
\hline & & & Hypo Real Estate Bank & Europe & 77.0 & 16 \\
\hline Austria & 8 & 3 & $\begin{array}{l}\text { Bank Austria } \\
\text { Erste Group Bank } \\
\text { Raiffeisen International Bank }\end{array}$ & $\begin{array}{l}\text { Europe } \\
\text { Europe } \\
\text { Europe }\end{array}$ & $\begin{array}{l}66.0 \\
51.0 \\
100\end{array}$ & $\begin{array}{l}1 \\
2 \\
6\end{array}$ \\
\hline Belgium & 5 & 3 & $\begin{array}{l}\text { Dexia } \\
\text { Fortis } \\
\text { KBC Group }\end{array}$ & $\begin{array}{l}\text { Europe } \\
\text { Europe } \\
\text { Europe }\end{array}$ & $\begin{array}{l}83.9 \\
58.2 \\
59.6\end{array}$ & $\begin{array}{l}1 \\
2 \\
3\end{array}$ \\
\hline Spain & 10 & 2 & $\begin{array}{l}\text { Santander } \\
\text { BBVA }\end{array}$ & $\begin{array}{l}\text { Europe } \\
\text { Europe }\end{array}$ & $\begin{array}{l}62.4 \\
40.9\end{array}$ & $\begin{array}{l}1 \\
2\end{array}$ \\
\hline France & 34 & 3 & $\begin{array}{l}\text { BNP Paribas } \\
\text { Crédit Agricole }^{2}\end{array}$ & $\begin{array}{l}\text { Europe } \\
\text { Europe }\end{array}$ & $\begin{array}{l}67.0 \\
61.0\end{array}$ & $\begin{array}{l}1 \\
2\end{array}$ \\
\hline & & & Société Générale & Europe & 51.0 & 3 \\
\hline Holland & 7 & 1 & ING Group & Europe & 48.2 & 1 \\
\hline Ireland & 3 & 2 & $\begin{array}{l}\text { Allied Irish Banks } \\
\text { Bank of Ireland }\end{array}$ & $\begin{array}{l}\text { United Kingdom } \\
\text { United Kingdom }\end{array}$ & $\begin{array}{l}40.1 \\
60.9\end{array}$ & $\begin{array}{l}2 \\
4\end{array}$ \\
\hline Italy & 30 & 1 & Unicredit & Europe & 61.7 & 1 \\
\hline Luxembourg & 3 & 1 & Espírito Santo Financial Group & $\begin{array}{l}\text { BENELUX - Eu- } \\
\text { rope }\end{array}$ & 50.9 & 1 \\
\hline United Kingdom & 14 & 4 & $\begin{array}{l}\text { Barclays } \\
\text { HSBC } \\
\text { Lloyds } \\
\text { Standard Chartered }\end{array}$ & $\begin{array}{l}\text { Europe } \\
\text { Europe } \\
\text { Europe } \\
\text { Asia }\end{array}$ & $\begin{array}{l}39.3 \\
61.8 \\
39.7 \\
98.0\end{array}$ & $\begin{array}{l}2 \\
3 \\
4 \\
5\end{array}$ \\
\hline Sweden & 6 & 2 & $\begin{array}{l}\text { Nordea Bank } \\
\text { SEB }\end{array}$ & $\begin{array}{l}\text { Scandinavia } \\
\text { Scandinavia }\end{array}$ & $\begin{array}{l}76.6 \\
47.0 \\
\end{array}$ & $\begin{array}{l}1 \\
2 \\
\end{array}$ \\
\hline
\end{tabular}

\footnotetext{
${ }^{1}$ Ranking at the domestic level in terms of Total Assets for 2008;

2 This corresponds to the geographic breakdown for the bank loan portfolio.

This table shows the listed banks in the EU-15 countries analyzed with significant asset (balance-sheet) exposure to the real estate market at the regional or international level (assets associated with the real estate sector have a weight of at least $40 \%$ in international markets). Data regarding the geographic exposure of banks is hand collected from the financial reports and accounts of the listed banks in the EU-15 (IAS 14 and IFRS 8). The table shows average figures for the period 2002-2008.

Source: BANKSCOPE.
}

subprime crisis. This suggests that banks in these countries have become more sensitive to the movements in the real estate market after the subprime crisis. For the other European countries, it is not clear that there is an increase in the sensitivity of bank returns to real estate market conditions after the subprime crisis.

Given the internationalization process of business activities by banks and the integration of the banking industry at a regional level, we also assess the impact of domestic, regional and international real estate activities on bank stock returns. Table 5 shows the listed banks in EU-15 that have a significant exposure to non-domestic, regional or international, real estate markets. 23 banks in 11 countries included in our sample had at least $40 \%$ of their real estate assets and loan holdings portfolio in non-domestic assets.
To account for the fact that, in many cases, the risks associated with banks' portfolio of real estate assets and loans holdings are non-domestic, we run the regressions of equations (1) and (2) for 11 countries of the EU-15, now considering a regional index as the proxy associated to the real estate market. The new estimates for the two models are presented in Table $6^{24}$.

Table 6 shows that the coefficient associated to real estate risk is positive and statistically significant for all the 11 European countries and for all the time frames considered. The results suggest that the use of regional indices may be a more accurate proxy for measuring banks' exposure to real estate market in countries with an internationalized banking sector. Particularly in those countries

\footnotetext{
$\overline{{ }^{24} \mathrm{We} \text { also }}$ run regressions using daily returns. Results are similar and are available upon request.
} 


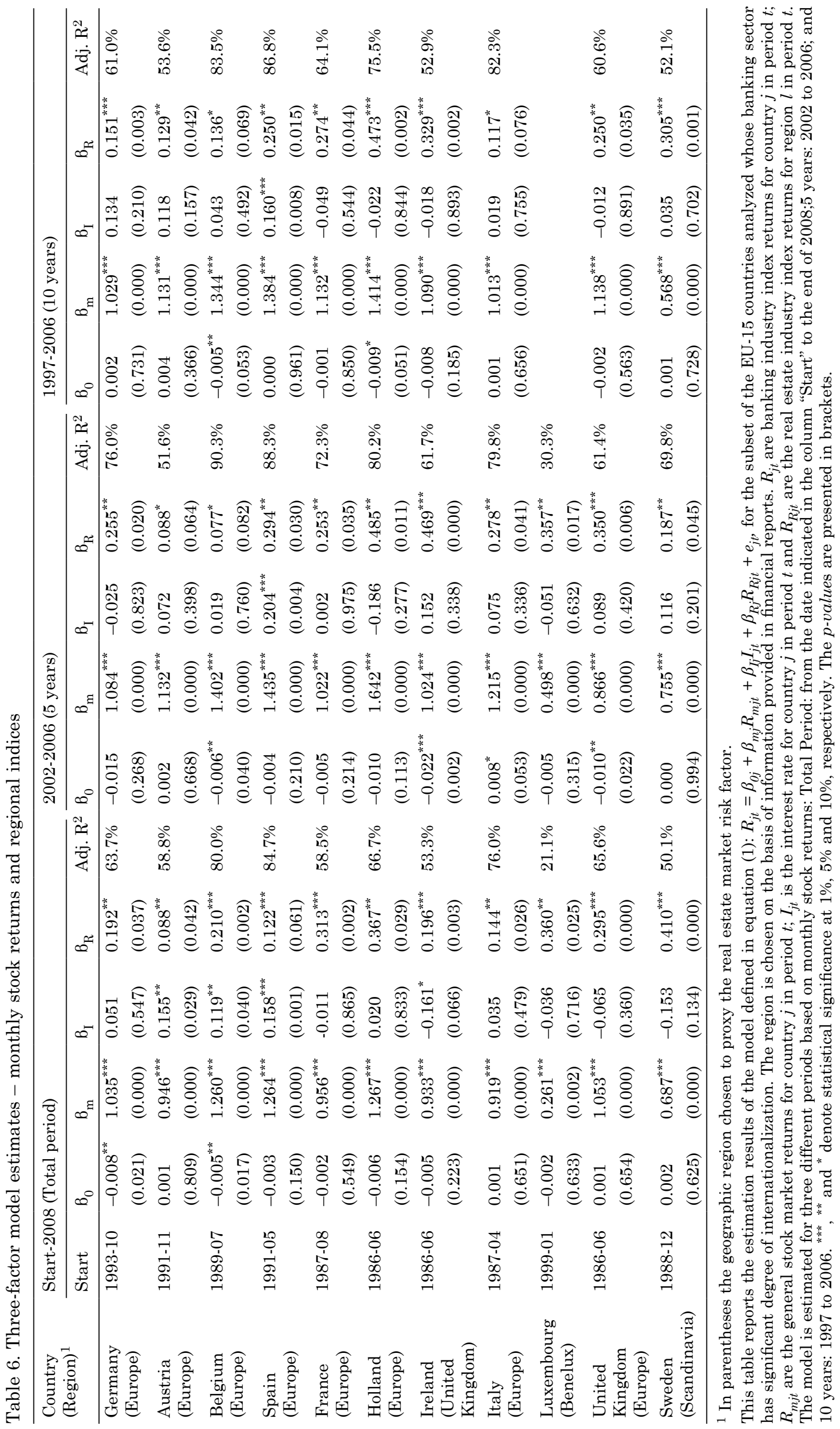


where listed banks have a very significant weight in the banking industry, their high exposure to international real estate asset and loan holdings precludes the use of domestic real estate companies returns to ascertain the sensitivity of real estate market returns. The high international banking activity in Spain and Belgium may help understand the unexpected negative signs and statistically significant real estate market risk coefficients in Tables 3 and 4. Given the reduced importance of the real estate domestic holdings in the portfolio of the main banks in those two countries, the relationship between bank returns and domestic real estate stock market returns does not properly reflect the true exposure of banks to real estate market risk.

\section{CONCLUSION}

Given the weight of real estate holdings on the balance sheets of banks, the objective of this study is to assess if bank stock returns are systematically affected by the real estate market conditions. The results show the existence of a positive and statistically significant relationship between bank stock returns and real estate market returns proxies suggesting that real estate risk could be a priced factor. This relationship between the banking industry and real estate is more significant when regional real estate indices are used as benchmark for real estate market conditions, driven by the fact that many European listed banks have significant non-domestic real estate holdings. The results further show an increasing influence of real estate market movements in bank stock returns after the subprime crisis in Ireland, Spain and the United Kingdom.

Our results have two important implications. First, regulators, managers and investors should monitor the exposure of banks to the real estate market, just as they monitor the exposure of banks to interest rates. Second, with respect to event study tests for the banking sector, the results suggest that the underlying return generating models should incorporate an additional risk factor: real estate. Finally, real estate market risk should be included alongside market and interest rate risks to estimate the cost of capital and to evaluate bank performance.

In this study, we look at the sensitivities of banking industry indices of the 15 EU countries. In a related working paper we estimate the sensitivities of individual bank stock returns to real estate market conditions and analyze their crosssectional differences. We show that individual bank sensitivities to real estate market risk are a negative function of bank size, and a positive function of the degree of bank's balance-sheet asset and loan exposure to the real estate market. Further, sensitivities are different across countries reflecting different banking and real estate institutional characteristics.

\section{REFERENCES}

Acharya, V.; Richardson, M.; Van Nieuwerburgh, S.; White, L. 2011. Guaranteed to fail: Fannie Mae, Freddie Mac and the debacle of mortgage finance. Princeton University Press.

Allen, M.; Madura, J.; Wiant, K. 1995. Commercial bank exposure and sensitivity to the real estate market, Journal of Real Estate Research 10(2): 129-140.

Crouhy, M.; Jarrow, R.; Turnbull, S. 2008. The subprime credit crisis of 07, Journal of Derivatives 16(1): 81110. http://dx.doi.org/10.3905/jod.2008.710899

Dell'Ariccia, G.; Igan, D.; Laeven, L. 2012. Credit booms and lending standards: evidence from the subprime mortgage market, Journal of Money, Credit and Banking 44(2-3): 367-384.

Demyanyk, Y.; van Hemert, O. 2011. Understanding the subprime mortgage crisis, Review of Financial Studies 24(6): 1848-1880. http://dx.doi.org/10.1093/ rfs/hhp033

Fama, E.; French, K. 1992. The cross-section of expected stock returns, Journal of Finance 47(2): 427-465. http://dx.doi.org/10.1111/j.1540-6261.1992.tb04398.x

Fama, E.; French, K. 1993. Common risk factors in the returns on stock and bonds, Journal of Financial Economics 33: 3-56. http://dx.doi.org/10.1016/0304405X(93)90023-5

Flannery, M.; James, C. 1984. The effect of interest rate changes on the common stock returns of financial institutions, Journal of Finance 34(4): 1141-1153. http://dx.doi.org/10.1111/j.1540-6261.1984.tb03898.x

Geltner, D. 1991. Smoothing in appraisal-based returns, Journal of Real Estate Finance and Economics 4(3): 327-345. http://dx.doi.org/10.1007/BF00161933

Geltner, D.; Ling, D. 2006. Considerations in the design \& construction of investment real estate research indices, Journal of Real Estate Research 28(4): 411444.

Ghosh, C.; Guttery, R.; Sirmans, C. 1997. The effects of the real estate crisis on institutional stock prices, Real Estate Economics 25(4): 591-614. http://dx.doi.org/10.1111/1540-6229.00729

Hancock, D.; Wilcox, J. 1993. Has there been a "capital crunch" in banking? The effects on bank lending of real estate market conditions and bank capital shortfalls, Journal of Housing Economics 3(1): 31-50. http://dx.doi.org/10.1006/jhec.1993.1003

Hancock, D.; Wilcox, J. 1994. Bank capital, loan delinquencies, and real estate lending, Journal of Housing 
Economics 3(2): 121-146. http://dx.doi.org/10.1006/ jhec.1994.1004

Hancock, D.; Wilcox, J. 1997. Bank capital, nonblank finance, and real estate activity, Journal of Housing Research 8(1): 75-105.

He, L.; Myer, N.; Webb, J. 1996. The sensitivity of bank stock returns to real estate, Journal of Real Estate Finance and Economics 12: 203-220. http://dx.doi.org/10.1007/BF00132268

Herring, R.; Wachter, S. 1999. Real estate booms and banking busts: an international perspective, Wharton Financial Institutions Center working paper. Available at: http://fic.wharton.upenn.edu/fic/papers/99/9927.pdf

Jahankhani, A.; Lynge, M. 1980. Commercial bank financial policies and their impact on market-determined measure of risk, Journal of Bank Research 11(3): 169-178.

Jimenez, G.; Salas, V.; Saurina, J. 2006. Determinants of collateral, Journal of Financial Economics 81(2): 255-281. http://dx.doi.org/10.1016/j.jfineco.2005.06.003

Kan, K.; Kwong, S.; Leung, C. 2004. The dynamics and volatility of commercial and residential property prices: theory and evidence, Journal of Regional Science 44(1): 95-123. http://dx.doi.org/10.1111/j.10859489.2004.00329.x

Lausberg, C. 2004. The real estate market risk of banks - evidence of its importance and consequences for managing risk in real estate lending, The ICFAI Journal of Financial Economics 2(2). http://dx.doi.org/10.2139/ssrn.268451

Lu, C.; So, R. 2005. Return relationships between listed banks and real estate firms: evidence from seven Asian economies, Journal of Real Estate Finance and Economics 31(2): 189-206.
Martins, A.; Serra, A.; Martins, V. 2012. The residential property prices in EU-15: importance of institutional factors. Mimeo.

Mei, J.; Lee, A. 1994. Is there a real estate factor premium?, Journal of Real Estate Finance and Economics 9: 113-126. http://dx.doi.org/10.1007/BF01099970

Mei, J.; Saunders, A. 1995. Bank risk and real estate: an asset pricing perspective, Journal of Real Estate Finance and Economics 10: 199-224. http://dx.doi.org/10.1007/BF01096939

Miles, D.; Pillonca, V. 2008. Financial innovation and European housing and mortgage markets, Oxford Review of Economic Policy 24(1): 145-175. http://dx.doi.org/10.1093/oxrep/grn005

Peek, J.; Rosengren, E. 1994. Bank real estate lending and the New England Capital Crunch, Journal of the American Real Estate and Urban Economics Association 22(1): 33-58. http://dx.doi.org/10.1111/1540-6229.00625

Peek, J.; Rosengren, E. 1996. Bank regulatory agreements and real estate lending, Real Estate Economics 24(1): 55-73. http://dx.doi.org/10.1111/15406229.00680

Quan, D.; Titman, S. 1999. Do real estate prices and stock prices move together? An international analysis, Real Estate Economics 27(2): 183-207. http://dx.doi.org/10.1111/1540-6229.00771

Tsatsaronis, K.; Zhu, H. 2004. What drives housing price dynamics: cross country evidence, BIS Quarterly Review March: 65-78.

Viale, A.; Kolari, J.; Fraser, D. 2009. Common risk factors in bank stocks, Journal of Banking and Finance 33: 464-472. http://dx.doi.org/10.1016/j.jbankfin.2008.08.019 